\title{
Is the UK saving enough and should we be compelled to save more?
}

Received: 20th July, 2005

\section{John Hawksworth}

is Head of Macroeconomics at PricewaterhouseCoopers in London. He has carried out many studies on pensions and savings in both the UK and other European countries over the past ten years. The views expressed in this paper are his own and should not be taken to be those of PricewaterhouseCoopers LLP.

\begin{abstract}
This paper reviews the evidence on whether the UK suffers from an inadequate savings rate, both at the macroeconomic level and at the individual level in relation to providing an adequate income in retirement. The paper goes on to argue that boosting savings requires a mix of policies, including state pension reform to reduce reliance on means-testing in the long term. Increased compulsory private savings is another option, but could have significant drawbacks if people on relatively low incomes were forced to save more than was optimal for them. An alternative policy of automatic enrolment in occupational schemes unless employees actively choose to opt out may be more attractive, possibly backed up by a reform of tax incentives to target these more on employers and lower income groups whose behaviour may be more responsive to such incentives.
\end{abstract}

Keywords: savings adequacy; pension projections; compulsory savings; auto-enrolment; pension reform options

John Hawksworth PricewaterhouseCoopers LLP

1 Embankment Place, London WC2N 6RH, UK.

e-mail: john.c.hawksworth@ uk.pwc.com

\section{Introduction}

There is a widespread view, reinforced by the conclusions of the first report of the Pensions Commission in October 2004, that the UK savings rate is too low, particularly in the context of an ageing population. At the

macroeconomic level, the concern is that a low level of national savings means that either UK investment is constrained, reducing long-term economic growth, or the country has to run an unsustainably large current account deficit, which might eventually lead to a loss of confidence by international investors and a run on the pound.

At an individual level, there are related concerns that current generations of workers are not saving enough for their retirement, which may result in relative poverty in old age, or a need to continue working much longer, or a higher burden on future taxpayers as future pensioners rely increasingly heavily on means-tested state benefits. This concern is amplified by the trend in recent years towards many employers scaling back their provision of occupational pensions.

One obvious question this raises is whether, if the UK is not saving enough, we should be compelled to save more. This paper considers this issue in more detail, drawing on relevant international 


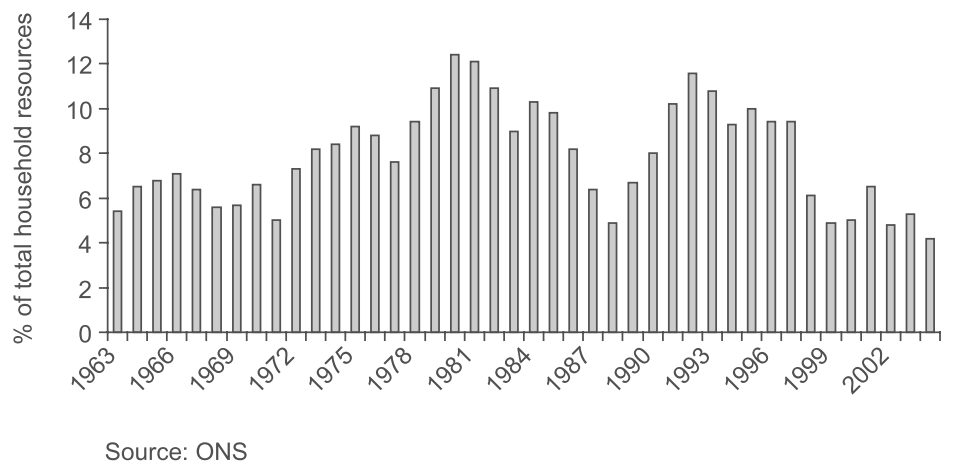

Figure 1: UK household savings ratio

experience in Australia in particular. The discussion is organised as follows:

- Adequacy of UK savings;

- International evidence on compulsion: the Australian experience;

- Arguments for and against compulsion in the UK;

- Conclusions.

\section{Adequacy of UK savings}

\section{Trends in UK savings rates}

The most commonly quoted measure of UK savings is the household savings ratio, where savings is measured as the difference between household disposable income and household consumption. As can be seen from Figure 1, this ratio fell in the mid-to-late 1980s boom, rose again in the early 1990s recession, but then fell back sharply in the late 1990s as the economy started to boom again, and has stayed relatively low.

The decline in the household savings ratio shown in Figure 1 is often taken as evidence that the UK now has a problem of inadequate savings, although it should be noted that variations in the ratio largely reflect cyclical variations in household borrowing rather than changes in the amounts being invested by households in financial assets. In recent years, in fact, net accumulation of financial assets by households seems to have been relatively strong, probably reflecting realised gains by older homeowners (and their inheritors) being recycled into financial assets. Furthermore, changes in household borrowing tend to be closely linked to movements in house prices (in particular through mortgage equity withdrawal), so both the asset and liability side of the household balance sheet have been increasing in recent years. In effect, rising house prices (and perhaps also rising share prices before 2000) have been doing much of the saving for households, allowing them to feel comfortable with a relatively low household savings ratio.

Another important point is that, with inflation now apparently anchored at a much lower level than was the case from the early 1970 s to the early 1990s, there is less need for additional saving in order to maintain real wealth levels. Bank of England analysis ${ }^{1}$ suggests that this lower inflation environment can explain a significant element in the decline in the household savings ratio between the early 1990s and the late 1990s.

The decline in the household savings ratio since 1997 might therefore be regarded as less of a concern once these additional factors are taken into account. Furthermore, it should also be noted that 


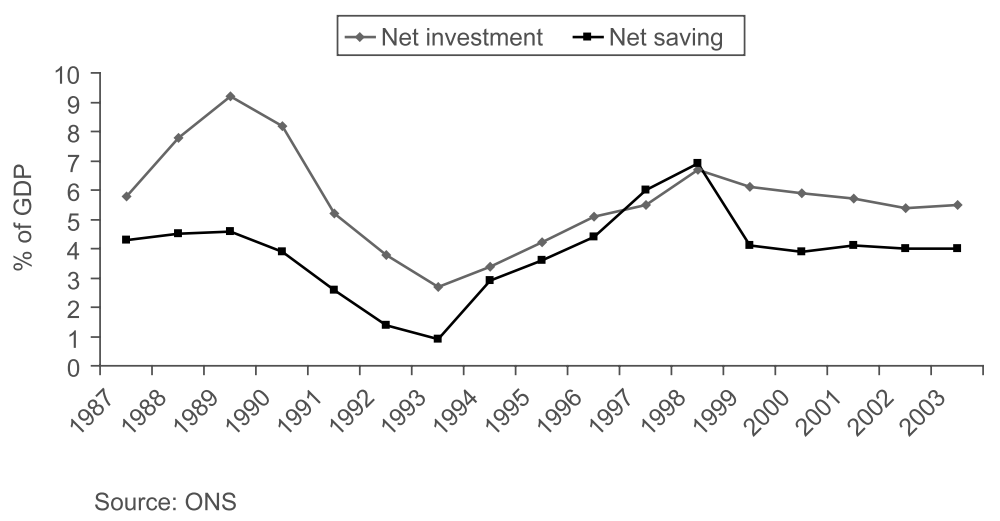

Figure 2: UK net national savings and investment

if a rapid increase in the savings ratio were to materialise over the next few years, associated with a sharp decline in household borrowing and consumption, this would not be particularly desirable as it might well push the UK economy into recession.

Nonetheless, there are still reasons to believe that a gradual upward adjustment in the UK's savings rate would be desirable. These can best be highlighted by focusing on a different measure, namely the $U K$ net national savings rate (see Figure 2). This also takes into account the savings of the corporate and public sectors, which can make an important contribution to determining the amount of domestically generated resources available to fund UK investment without borrowing from abroad and thereby potentially running up unsustainable external debts in the long term.

As illustrated in Figure 2, there has been a decline in net national saving since 1998, although the ratio remains well above its low point in the early 1990s. This has to some extent been mirrored by a decline in net national investment since 1998, although this has been mitigated by increased borrowing from abroad. This has, however, resulted in an increase in the UK current account deficit, to around 2 per cent of GDP in 2004 , to fill the funding gap between domestic savings and investment. At present, a deficit of this size does not pose significant concerns, but if it were to go much higher then this situation could change, leading to a sharp fall in the pound. This, while good news for UK exporters, could push up inflation and interest rates. If UK investment is to increase in order to support longer-term growth, therefore, this really needs to be funded in the medium term through higher net national savings rather than by increased borrowing from abroad.

\section{International comparisons}

As illustrated in Figure 3, relatively low levels of net national saving are not a new phenomenon for the UK. Over the period 1987-2003, the average UK net savings rate of 4.1 per cent of GDP was slightly lower than the US (4.5 per cent) and significantly lower than other major European economies (6.8-7.5 per cent) and Japan (12.7 per cent, although declining significantly over time). This in turn has been associated with a relatively low investment to GDP ratio in the UK and, indeed, the USA, despite persistent current account deficits in both countries. 


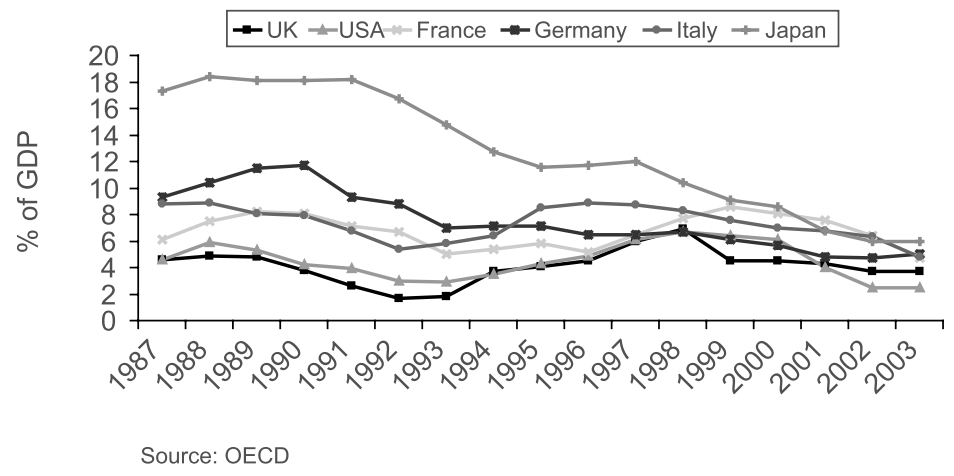

Figure 3: Net national savings rates for major economies

On the other hand, it would be hard to argue that there is any simple relationship between savings and investment ratios and economic growth. The UK has seen the second highest average GDP growth rate since 1987 after its low-saving cousin the USA, while higher savings and investment rates in the other major EU economies and particularly Japan have been associated with relatively slow growth over this period. This may reflect the fact that the quality of investment in the USA and, to a lesser degree, the UK has been relatively high, as indicated by the continued willingness of international investors to fund the current account deficits in these countries. It may also reflect the fact that high household savings rates in Euroland and Japan have generally been associated with an endemic lack of consumer confidence in these countries that has made it difficult for them to sustain strong domestic demand growth.

These comparisons make clear that high national savings rates are not an end in themselves. They need to be combined with mechanisms to ensure that the funds are channelled into the most productive investments. In the period from the 1960s to the 1980s, the bank-based systems prevalent in other European countries and, in particular, Japan seemed to be relatively successful in achieving this, but the experience since the early 1990s has been more favourable to the market-based financial systems in the USA and the UK.

This is not to say, however, that US and UK growth could not have been greater had their savings and investment rates been higher: standard economic theory would suggest that this would have been the case given a reasonably efficient system of financial intermediation. Recent estimates by the National Institute of Economic and Social Research (NIESR) ${ }^{2}$ suggest that annual net national saving could be anywhere between £16bn and f66bn below the optimal level needed to sustain trend real GDP growth of 2.5 per cent in the long run.

\section{Adequacy of individual savings for retirement}

Any such national savings gap could in principle be filled through any combination of individuals, companies and government saving more. Much of the public debate on this issue, however, has focused on the somewhat narrower - but still very important - issue of whether individuals are saving enough for their retirement, given what they can 
reasonably expect in terms of state pension provision. The Association of British Insurers (ABI), ${ }^{3}$ for example, has estimated that over 12 million people are not saving enough to ensure an adequate income in their old age. The Pensions Commission estimated in their first report that 'around 9 million people may be under-saving, some by a small amount, some severely'. ${ }^{4}$ The report also states, however, that this should be regarded as a minimum estimate of those under-saving in pensions: the true figure may already be higher and would be likely to grow over time as the shift from Defined Benefit (DB) to Defined Contribution (DC) schemes continues in the private sector, a shift which is generally associated with significant reductions in employer pension contributions.

As discussed in the Pensions Commission report (pp. 158-159), estimates of the number of people under-saving rely on a large number of simplifying assumptions and suffer from imperfect data on current pension saving together with an almost total lack of data on accumulated past stocks of pension saving. Given these severe data limitations, PricewaterhouseCoopers $(\mathrm{PwC})$ has not attempted to produce estimates of its own of the number of people under-saving. Instead estimates have been made ${ }^{5}$ of what the total future payouts from UK private pensions might be, based on alternative assumptions on, in particular, rates of return on pension fund investments and future contribution rates. This provides a cross-check on some similar analysis in Section 4 of the Pensions Commission report (pp. 144-149 and Appendix B). In common with that report, this paper focuses on the adequacy of total projected incomes for pensioners in 2050.

The Pensions Commission report estimates (p. 145) that, depending on the extent to which female average retirement ages rise to match those for men in response to the equalisation of male and female state pension ages between 2010 and 2020, the 'target' proportion of GDP that needs to be transferred to pensioners in 2050 to keep their relative living standards ${ }^{6}$ the same as now would have to increase from around 9.1 per cent of GDP in 2002 to around 13.9-16.1 per cent of GDP in 2050 (see Figure 4). How likely is this target to be achieved?

\section{Projected state pension payments}

Starting with state transfers to pensioners, the Pensions Commission relies on government estimates that these will increase from around 6.1 per cent of GDP in 2002 to around 6.9 per cent of GDP in 2050. In practice, it is possible that these state transfers could be higher if private pension incomes do not grow in line with average earnings as the government assumes, so pushing more future pensioners on to means-tested benefits. The extent of this effect is highly uncertain, but could be significant.

Income from unfunded public pension schemes also needs to be taken into account. In December 2004, the Treasury $^{7}$ published for the first time long-term projections for unfunded public service pensions, indicating a rise from 1.5 per cent at GDP in 2003/4 to around 2.2 per cent of GDP by 2050 . These projections take into account planned reforms to these public pension schemes, in particular a rise in normal retirement ages to 65 . Taking this latter effect into account, it is assumed that total payments to pensioners from these unfunded pension schemes will increase from around 0.8 per cent of GDP at present (53 per cent of the total) to around 1.5 per cent of GDP (c. 70 per cent of the total of 2.2 per cent) by 


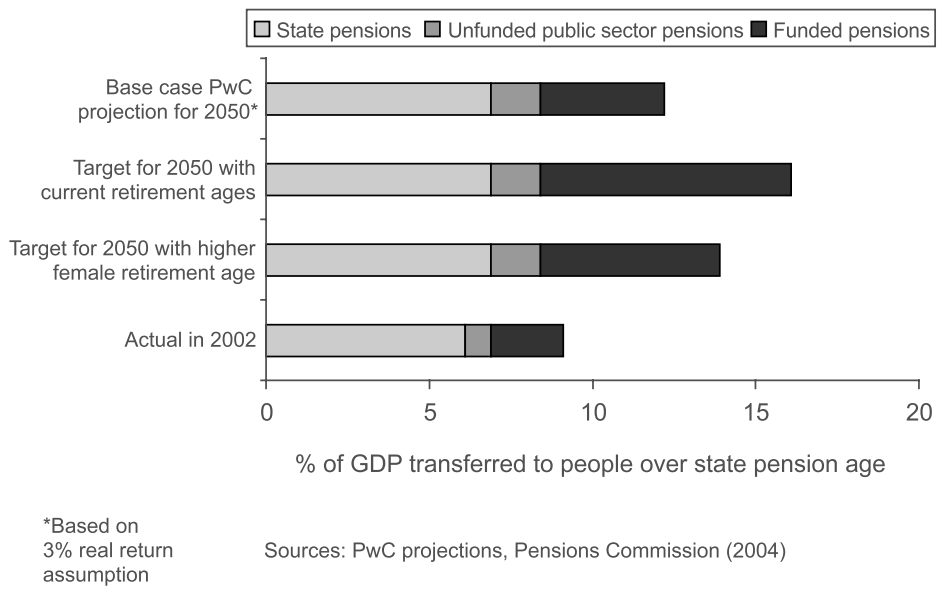

Figure 4: Current transfers to pensioners and projected and target levels of these transfers in 2050

2050. This seems more plausible than the Pensions Commission assumption that these payments remain at only 0.8 per cent of GDP up to 2050.

This analysis therefore implies a total government payout of around 8.4 per cent of GDP and a potential gap to be filled by private sector pensions of around 5.5-7.7 per cent of GDP, depending on the assumptions made about future average retirement ages. Can the private sector fill this gap?

\section{Private pensions projections}

To address this issue a model has been constructed that looks separately at each cohort of the UK population born between 1955 and 1985. These people will be aged 65-95 in 2050 and so would make up the great majority of the UK pensioner population at that date. Private pension contributions, fund performance and payouts for a representative individual in each annual age cohort are modelled, and are then weighted according to the size of each cohort to produce the aggregated results. People are assumed to start saving at age 25 and to continue to do so until they retire at age 65 .
Pension fund assets during the accumulation phase are assumed to rise at a net real rate (after costs) that varies from 2-5 per cent per annum in the various cases considered. Annuity rates are set based on an average life expectancy of 85 and a real net bond return of 1.3 per cent on remaining funds during the decumulation phase.

Historic average private pension contributions are based on estimates in the Pensions Commission report for the period since 1991, and are assumed constant at 1991 levels in 1981-1990. In the future, the base case assumption, again in line with Pensions Commission projections, is that average private pension contributions (in total for employers and employees) decline gradually from 3.8 per cent of GDP in 2003 to 2.9 per cent of GDP in 2030, reflecting the assumed shift from $\mathrm{DB}$ to DC schemes. For simplicity, the same average pension contribution rate is assumed to apply to all cohorts aged between 25 and 65 in a given year. Alternative cases are also considered with pension contribution rates from 2030 set at between 2-5 per cent of GDP and a gradual transition in each case between now and 2030. 
Table 1: Alternative projections of total private pension income in 2050

\begin{tabular}{llllll}
\hline & & \multicolumn{3}{l}{ Net real rate of return on pension fund } \\
Percentage of GDP in $\mathbf{2 0 5 0}$ & & $\mathbf{2 \%}$ & $\mathbf{3 \%}$ & $\mathbf{4 \%}$ & $\mathbf{5 \%}$ \\
\hline Private pension & $2.0 \%$ & 2.6 & 3.2 & 4.0 & 5.1 \\
average contribution & $2.9 \%$ & 3.1 & 3.8 & 4.7 & 5.9 \\
rate (\% GDP) & $4.0 \%$ & 3.7 & 4.5 & 5.5 & 6.9 \\
& $5.0 \%$ & 4.3 & 5.2 & 6.3 & 7.8 \\
\hline
\end{tabular}

Source: author's estimates

Table 1 summarises the results of the private pension modelling for real net rates of return on pension fund assets of between 2-5 per cent per annum and long-term private pension contributions rates of between 2-5 per cent of GDP (these are the key assumptions for sensitivity analysis in this model).

For the base case contribution rate of 2.9 per cent of GDP and real rates of return of 3 per cent, which broadly correspond to the assumptions for the main case presented by the Pensions Commission, the model suggests private pension payments of around 3.8 per cent of GDP in 2050. The estimates here are similar to the Pensions Commission report estimate of around 3.4-4.2 per cent of GDP for comparable assumptions (see Table 4.5 on p. 147 of their report), but it is important to recognise the many uncertainties surrounding any such long-term projections. This is illustrated by the alternative estimates in Table 1 , which vary from only 2.6 per cent of GDP in a case with only a 2 per cent real rate of return and a 2 per cent contribution rate, to 7.8 per cent of GDP with both the real rate of return and the contribution rate set at 5 per cent. These extreme cases are, however, relatively improbable.

Comparing the estimates of private pension payments in 2050 with the target of around 5.5-7.7 per cent of GDP derived earlier, it can be seen that, based on a reasonably conservative real rate of return assumption of 3 per cent, the gap would be around 1.7-3.9 per cent of GDP, or around $£ 20-45 b n$ at current values. To bridge this gap based on the lower bound of the target range (which assumes, plausibly enough perhaps, that female average retirement ages will eventually rise to match those of men) would require average long-term pension contributions to rise from around 2.9 per cent of GDP in the base case to around 5.5 per cent of GDP, an increase of around $\mathcal{E}^{3} 3 \mathrm{bn}$. If female retirement ages remain lower on average than those of men, however, then the required pension contribution increase would be higher.

If it is accepted that the UK is not currently saving enough for its retirement, does this imply that people should be compelled to save more? Before considering this question in more detail, it is useful to review experience on the effects of compulsion from the closest available international comparator: Australia.

\section{International evidence on compulsion: The Australian experience}

The Australian experience, although different in important respects from the UK (eg in terms of the way in which the introduction of compulsion was mediated through a national bargaining process that allowed wages to adjust to offset impacts on employer costs to a significant degree), is probably the most relevant international comparator for quantifying the potential effects of 
Is the UK saving enough?

Table 2: Overview of results of empirical studies on the effects of compulsion on other savings in Australia

\begin{tabular}{lll}
\hline Study & Period & Offset (\%) \\
\hline Fitzgerald and Harper (1992) & & 50 \\
Corcoran and Richardson (1995) & 1988 & 17 \\
Covick and Higgs (1995) & $1980 \mathrm{~s}$ & 37 \\
Morling and Subbaraman (1995) & $1960-94$ & 75 \\
Gallagher (1997) & $1966 / 67-2000 / 01$ & $30-50$ \\
Connolly and Kohler (2004) & (190 & 38 \\
\hline
\end{tabular}

Note: This table is adapted from Table 2 in Connolly and Kohler (2004)

compulsion in the UK. This is because circumstances in Latin America are too different to be of much relevance to the UK, while earlier quasi-compulsory schemes in the Netherlands and Switzerland were introduced very gradually a long time ago, which makes it difficult to isolate the impact of these policy shifts on savings. The Swedish regime, where compulsion operates through the state scheme, is another possible comparator, but it is beyond the scope of this paper to look at recent experience there in any detail.

Compulsory employer contributions (the Superannuation Guarantee), a system where a 3 per cent employer pension contribution was awarded in lieu of a 3 per cent wage increase, was extended to apply to most employees in 1992 after being introduced in 1986. The scheme was intended to boost deficient levels of saving and expand pension coverage, which had previously been restricted to higher earners. The contribution rate has been gradually raised to its current level of 9 per cent, although it has been estimated that a contribution rate of around 18 per cent is required for an adequate replacement rate to income in Australia. ${ }^{8}$

In 1988, before compulsion was introduced, the level of private pension coverage in Australia was only around 40 per cent of the workforce, not significantly different from current coverage levels in the USA and the
UK. However, by 2001, following the introduction of compulsory contributions, superannuation coverage had more than doubled and stood at just under 87 per cent of the total workforce in Australia.

The key issue here is whether compulsion has led to additional total savings or just a switch of existing voluntary savings, with little or no net effect. Household savings rates in Australia fell from nearly 10 per cent in the mid 1970s to 0.5 per cent in 2004, but the question is whether savings would have been even lower without compulsion. This is a difficult question to answer and it is not surprising that there are a range of different estimates of the impact of compulsion in Australia, as summarised in Table 2.

Morling and Subbaraman (1995) found a relatively large offset coefficient of 75 per cent for net superannuation contributions, suggesting that about three-quarters of additional compulsory saving has been offset by changes in other saving. However, their results are not strictly comparable with the other studies for two reasons. First, during the period covered by their data (1960-94), superannuation comprised mainly voluntary contributions. Second, their coefficients summarise the behaviours of both the contributing and withdrawing cohorts.

The more recent Reserve Bank of Australia (RBA) study by Connolly and Kohler $^{10}$ used annual data from 1966/67 
to 2001/02. They modelled household voluntary savings as a function of labour income, compulsory superannuation, net wealth and the debt-to-income ratio, focusing their analysis on what effect compulsory and voluntary superannuation had on voluntary saving. Their estimate of the offset of compulsory superannuation was around 38 per cent, within Gallagher's (1997) expected range of 30-50 per cent based on a review of past studies. ${ }^{11}$

Their results also suggest that households reduced their voluntary superannuation contributions to offset compulsory superannuation, but large standard errors made this conclusion tentative. However, some supporting evidence on this can be gleaned from the Australian Household Expenditure Survey, which found that although the total value of voluntary contributions has grown since the 1980s, this has been driven by high-income earners, while lower to middle-income earners reduced their contributions. Households who may otherwise have chosen to save through voluntary superannuation may be increasingly relying on their compulsory contributions.

Connolly and Kohler also attempt to estimate the net effect that compulsory superannuation has had on the savings rate. They conclude that the savings rate would have been lower by around 1.5-2 per cent of GDP by 2001/02 if it were not for the introduction of compulsory superannuation.

The conclusion to draw from the Australian evidence is that it would be reasonable to assume that around $30-50$ per cent of any additional pension saving due to compulsion is likely to be diverted from other savings in aggregate, but with this ratio probably being below 30 per cent for lower income groups and above 50 per cent for higher income groups.

\section{Arguments for and against compulsion for the UK}

\section{Arguments for compulsion}

One possible conclusion from the analysis of UK savings in the first section might be that voluntary savings alone cannot deliver the required increase in retirement income necessary to avoid an increase in relative pensioner poverty in future decades. This might suggest the need for an increase in compulsion beyond what is currently required through National Insurance Contributions to the State Second Pension (S2P) or an appropriate contracted-out scheme.

This case might be supported by arguments that, at present, the combination of the Basic State Pension (BSP) plus S2P will produce a relatively low earnings replacement rate in retirement as compared with other countries (see Figure 5, which is based on OECD analysis for someone retiring in 2050 in the different countries shown with varying lifetime income levels). The UK might not wish to go as far as countries like Sweden and the Netherlands in providing, through mandatory or quasi-mandatory schemes, a 60-70 per cent replacement rate for those earning up to twice the national average, but it has been argued recently by Adair Turner ${ }^{12}$ that some intermediate target replacement rate of perhaps around 30-40 per cent for those on twice average earnings (similar to US or Australian levels), as compared with only around 20 per cent under the current UK BSP/S2P regime, might be a reasonable compromise.

The main argument in favour of this position is that, without some additional degree of compulsion, individuals may not provide as much for their retirement as they would wish, given well-known tendencies for savings decisions to suffer 


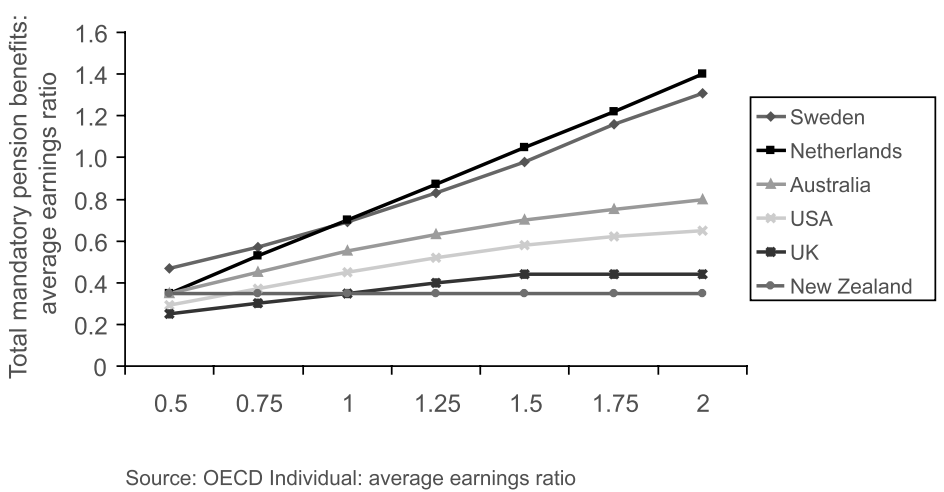

Figure 5: Gross mandatory (or quasi-mandatory) pension replacement ratios in different countries

from myopia, procrastination and inertia. ${ }^{13}$ To the extent that the costs of this 'irrationality' fall only on the individual, it could be argued that it is not the business of government to intervene to attempt to correct such decisions, particularly as the government can only do so in a highly imperfect manner based on some view of average preferences. But, as noted above, if individuals fail to save for their own retirement, then they are likely to come back to the state for support, either via the means testing system, or via political pressure for a higher basic state pension from the future 'grey lobby', who will be relatively more numerous in future and so more politically powerful.

The other side of the argument for compulsion is that alternatives, such as increased tax incentives for voluntary saving, are likely to be relatively ineffective, since many past studies suggest that they largely result in money being switched between different types of financial instrument, rather than increasing overall savings levels. This certainly seems to hold true for higher income groups in relation to products such as 401(k) schemes in the USA, or TESSAs and PEPs in the UK (see, for example, the discussion in Attanasio et al., 2004),${ }^{14}$ although it can be argued (see below) that the net effects of such incentives could be greater if targeted on employers and lower earners in the right way.

\section{Arguments against compulsion}

Research that PwC carried out recently for the $\mathrm{ABI}^{15}$ suggests that compulsion might be effective in boosting the amount going into private pensions, although as noted above the Australian evidence suggests that around 30-50 per cent of any additional compulsory pension contributions would probably be offset by reductions in other voluntary savings. Furthermore, if the compulsory rate was set too low, it could lead to some companies and individuals levelling down to this rate if they took this as a signal from government that this was considered to be adequate to deliver a reasonable income in retirement. Nonetheless, even after taking these offsetting effects into account, the PwC report estimated that setting compulsory contributions at 3 per cent each for employers and employees could produce a net increase in savings of around $\mathcal{E}^{5} \mathrm{bm}$ per annum, although there could also be an additional tax relief cost to the Exchequer of around $\mathcal{E}^{2.8 \mathrm{bn} .}{ }^{16}$

The report also highlighted the drawbacks of compulsion, however, and suggested that a package of other 


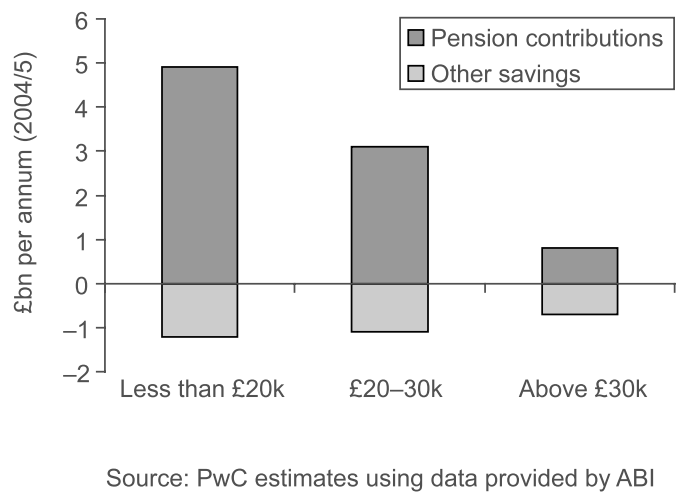

Figure 6: Impact of compulsion on savings by income group

measures might be a viable alternative. The first priority here might be to reform state pensions so as to reduce means-testing, which tends to act as a disincentive to save and, more importantly in practice, as a barrier to selling savings products due to fear of later mis-selling charges. The second priority might be to boost voluntary savings through a combination of measures such as auto-enrolment, matching contributions for lower income groups (which have been shown to be relatively effective in Savings Gateway pilot schemes in the UK) and possibly also, as suggested by the ABI, enhanced tax incentives for companies to enrol their staff in pension schemes, particularly for small and medium-sized firms that might otherwise be reluctant to do so given the costs involved in running an occupational pension scheme.

In relation to the impact of compulsion, the $\mathrm{PwC}$ report also confirmed that there would be likely to be important differences in the impact of compulsion across the income distribution, with most of the net addition to savings coming from those earning less than $\mathcal{E}^{20,000}$ per annum (see Figure 6).

The intuition behind the results shown in Figure 6 is that higher income households (ie those earning above ,30,000 per annum) with significant voluntary savings may just react to compulsion by shifting funds from voluntary to compulsory savings 'pots', with little or no net effect on their total savings. Lower income households who currently save little or nothing voluntarily, however, may not be able to do this and so may be obliged to increase their total savings under compulsion. Whether this is actually desirable, however, may vary from case to case. For a low income household with significant debts, for example, it may be better for them to use any surplus income to pay off these debts rather than to contribute to compulsory savings schemes. In other cases, compulsory savings may be at the expense of essential household expenditure, or other desirable investments such as saving for a deposit on a house or funding education and training courses to improve future career prospects. Making employers pay the compulsory contributions may not resolve this problem if the costs are just passed back to employees through lower wages (as has been the case to a significant degree in Australia, although this was agreed through national bargaining between employers and unions).

In summary, the net impact of 
compulsion on total savings remains uncertain and, to the extent that there is such an effect, it may fall disproportionately on lower income households who would do better to use their limited resources in other ways. This would suggest that the government should think carefully before going down the compulsion route. As noted above, there may be a viable alternative in the form of auto-enrolment in occupational or stakeholder pension schemes provided that some minimum employer contribution is made and that the employee does not positively decide to opt out. This has been shown ${ }^{17}$ to be effective in the USA by putting inertia on the side of pension savings, while still leaving room for people to opt out if they strongly feel it is in their interests to do so.

The PwC report for the ABI estimated that, if auto-enrolment rates were set at 3 per cent for both employers and employees initially, then there could be a net boost to savings of around $f^{2.5 b n}$ per annum based on plausible assumptions on opt-out rates. If auto-enrolment default contribution rates were gradually increased over time, as in the Save More Tomorrow schemes discussed by Benartzi and Thaler, ${ }^{18}$ then the longer-term effects could be greater than this, particularly if supported by other measures such as tax incentives for employers that succeed in enrolling a certain proportion (say, more than two-thirds) of their employees, as proposed by the ABI.

\section{CONCLUSIONS}

The analysis in this paper lends some support to the view that the UK suffers from an inadequate savings rate, both at the macroeconomic level in relation to maintaining a reasonable ratio of wealth to national income, and at the individual level in relation to providing an adequate income in retirement. Projections by PwC suggest a potential long-term savings gap of the order of around f30bn, although this estimate is subject to considerable uncertainty depending on future economic, financial and demographic conditions.

Boosting savings requires a mix of policies, including state pension reform to reduce reliance on means-testing in the long term. Increased compulsory private savings is another option, but it could have significant drawbacks if people on relatively low incomes were forced to save more than was optimal for them. An alternative policy of automatic enrolment in occupational schemes unless employees actively choose to opt out may be more attractive, possibly backed up by a reform of tax incentives to target these more on employers and lower income groups whose behaviour may be more responsive to such incentives.

\section{References}

1 Davey, M. (2001) 'Saving, wealth and consumption', Bank of England Quarterly Bulletin, Spring.

2 Pomerantz, O. and M. Weale (2005) 'Are we saving enough? The macroeconomics of the savings gap', National Institute Economic Review, No. 193, January, pp. 79-93.

3 ABI (2004) State of the Nation's Savings 2004, November.

4 Pensions Commission (2004) Pensions: Challenges and Choices, the First Report of the Pensions Commission. The quote comes from page xi of the Executive Summary.

5 Hawksworth, J. (2005) 'Is the UK saving enough?', PricewaterhouseCoopers UK Economic Outlook, March (available from research archive at www.pwc.com/uk/economicoutlook). The private pension projections in Table 2 are taken from this earlier paper by the author.

6 Defined here as the ratio of pensioner incomes to average net incomes across the population as a whole.

7 HM Treasury (2004) Long-term Public Finance Report, December, London (see Table 5.1 on p. 50).

8 Fitzgerald, V. W. (1993) 'Superannuation and national saving: Much ado about nothing or all's well that ends well?', paper presented at the First Annual Colloquium of Superannuation Researchers, University of Melbourne, July. 
9 Morling, S. and Subbaraman, R. (1995) 'Superannuation and saving', Reserve Bank of Australian Research Discussion Paper No. 9511.

10 Connolly, E. and Kohler, M. (2004) 'The impact of superannuation on household saving', Reserve Bank of Australia Research Discussion Paper RDP2004-01.

11 Gallagher, P. (1997) 'Assessing the national savings effects of the government's superannuation policies: Some examples of the new RIMGROUP national savings methodology', paper given at the Fifth Annual Colloquium of Superannuation Researchers, University of Melbourne, Conference Paper 97/3.

12 Turner, A. (2005) 'Pensions policy: Political choices and macroeconomic issues', speech at the London School of Economics, 8th March (available from www.pensionscommission.org.uk).

13 This conclusion follows from extensive research in the behavioural economics and psychology field, as summarised in the first report of the Pensions Commission, pp. 208-209.
14 Attanasio, O. P., Banks, J. and Wakefield, M. (2004) 'Effectiveness of tax incentives to boost (retirement) saving: Theoretical motivation and empirical evidence', IFS discussion paper, December.

15 PricewaterhouseCoopers (2005) 'Bridging the savings gap: An evaluation of voluntary and compulsory approaches to pension reform',

PricewaterhouseCoopers report for the ABI, June (available from the publications section at www.abi.org.uk).

16 Assuming that tax relief is retained for compulsory pension contributions.

17 Madrian, B. and Shea, D. (2001) 'The power of suggestion: Inertia in $401(\mathrm{k})$ participation and savings behaviour', Quarterly Journal of Economics, Vol. CXVI, No. 4, pp. 1149-1187.

18 Thaler, R. H. and Benartzi, S. (2004) 'Save more tomorrow: Using behavioural economics to increase employee saving', Journal of Political Economy, Vol. 112, No. 1, Pt 2, pp. 164-187. 